\title{
LITERATURA E REPRESSÃO: UMA ANÁLISE DO CONTO “DODORA”, DE BERNARDO KUCINSKI
}

\author{
Suzeli Santos Santana* \\ Cristiano Augusto da Silva Jutgla*
}

\begin{abstract}
RESUMO: O artigo analisa o conto "Dodora", de Bernardo Kucinski, publicado em Você vai voltar pra mim e outros contos (2014), obra de teor testemunhal que tematiza o contexto da ditadura civil-militar brasileira. Apesar do livro ter sido publicado após o processo de redemocratização, nota-se a necessidade de rememorar o passado no tempo presente, na perspectiva de evitar a perpetuação do autoritarismo de outrora. Nesse ínterim, debatem-se os impactos traumáticos da ditadura, sobretudo a "síndrome da tortura", medo constante provocado pelo clima de opressão da época. A leitura que se propõe do conto de Kucinski, portanto, está orientada a entender de que maneira a literatura produzida no contexto pós ditadura civil-militar elabora a repressão política e suas sequelas. Para tanto, esse estudo, eminentemente bibliográfico, recorre a estudiosos de diversas áreas do conhecimento, dentre eles, Ginzburg, Sarlo, Seligmann-Silva e Viñar.
\end{abstract}

PALAVRAS-CHAVE: Ditadura civil-militar; Literatura de testemunho; Memória; Tortura; Trauma.

\footnotetext{
* Mestre em Letras: Linguagens e representações, pela Universidade Estadual de Santa Cruz (Uesc).

${ }^{* *}$ Doutor em Literatura Brasileira pela Universidade de São Paulo (Usp). Professor Titular da Universidade Estadual de Santa Cruz (Uesc). Orientador dessa pesquisa.
} 
Tantas as perguntas, tantas as denúncias, tantos os indícios de culpa que só resta aceitar a sentença e beber, sem pressa, a cicuta. (Lara de Lemos).

Seligmann-Silva (2005, p. 76), em “Literatura e trauma: um novo paradigma”, elucida que "a literatura ao longo do século XX foi abalada pela história". Nessa perspectiva, diante de um período histórico marcado por genocídios, guerras e ditaduras - o século XX, considerado a "era das catástrofes", por Eric Hobsbawm (1995) - muitos artistas e intelectuais estabeleceram um intrínseco diálogo entre história e arte em suas produções. Nesse contexto, as experiências de eventos-limite, como tais catástrofes, levaram à impossibilidade e, ao mesmo tempo, à necessidade de uma nova narrativa que apresenta as fragmentações do sujeito perante vivências traumáticas, mas que também se expressa como ferramenta de resistência e denúncia:

O estudo do testemunho exige uma concepção da linguagem como campo associado ao trauma. A escrita não é aqui lugar dedicado ao ócio ou ao comportamento lúdico, mas ao contato com o sofrimento e seus fundamentos, por mais que sejam, muitas vezes [, ] obscuros e repugnantes. O século XX se estabeleceu como tempo propício para testemunho, em virtude da enorme presença das guerras e dos genocídios. Para o sujeito da enunciação do testemunho, entre o impacto da catástrofe e os recursos expressivos, pode haver um abismo intransponível, de modo que toda formulação pode ser imprecisa ou insuficiente (GINZBURG, 2008, p. 63).

Dessa forma, entre a impossibilidade e a necessidade de narrar após vivenciar eventos traumáticos, os sobreviventes dessas catástrofes passam a contar suas experiências e as de outrem a fim de manter a memória de todas as vítimas, de se fazer justiça e também na tentativa de elaborar o vivido. A narrativa desses traumas, portanto, constitui a literatura de testemunho. 
Em 2014, ano em que se completaram 50 anos do golpe civil-militar de 1964, o escritor paulista Bernardo Kucinski publicou a obra Você vai voltar pra mim e outros contos, livro que retoma memórias da ditadura civil-militar brasileira. A importância dessa obra, de teor testemunhal, justifica-se pela necessidade de restituir a memória coletiva de um passado recente da história do Brasil, marcado pela violência e autoritarismo, que ameaça constantemente se repetir nos dias vigentes.

Bernardo Kucinski (1937-) militou na resistência contra a ditadura civil-militar, sendo preso, exilado e passado pela experiência de testemunhar o desaparecimento de sua irmã, Ana Kucinski, e de seu cunhado, Wilson Silva, em 1974. Nesse sentido, assim como o fez em K. (2011), cujo romance tem seu enredo centrado na busca do pai K. pela filha desaparecida, Kucinski reconstrói, novamente, no plano da linguagem literária, os violentos momentos do qual foi testemunha.

Sob esse prisma, Você vai voltar pra mim e outros contos (2014), de Bernardo Kucinski, é aqui considerada como uma obra testemunhal porque o escritor apresenta não só a experiência traumática e dolorosa de pessoas que não puderam falar, ao atuarem como testemunhas da conjuntura política de seu tempo, como também recompõe o cenário histórico das décadas de 1960 e 1970 e as cicatrizes deixadas por essa época.

Assim, na perspectiva de pensar o teor testemunhal, analisar-se-á o conto "Dodora", que trata de "temas-limite", como a tortura e a memória traumática - oriundas da ditadura civil-militar brasileira -, na perspectiva de entender a elaboração de eventos traumáticos através da linguagem, assim como a necessidade de narrar o vivido de forma ética.

\footnotetext{
${ }^{1} \mathrm{O}$ objeto de estudo dessa pesquisa é a edição original de Você vai voltar pra mim e outros contos, publicada em 2014, entretanto, vale ressaltar que houve uma revisão na $1^{a}$ reimpressão da obra, de 2015, na qual o conto "Dodora" e a personagem homônima passaram a ser "Heliodora". Esta informação é relevante, pois incita questionamentos acerca dos motivos que levaram Kucinski a esta modificação, assim como os novos sentidos que o nome da personagem sugere.
} 


\section{"Dodora" e a síndrome da tortura}

O conto "Dodora", de Bernardo Kucinski, trata dos impactos traumáticos oriundos do regime militar brasileiro. Ora em primeira pessoa, ora em terceira pessoa, e sem a presença de diálogos, conta-se a história da complexa personagem Dodora, uma guerrilheira que delata precipitadamente o grupo do qual fazia parte, possivelmente por sofrer de uma "síndrome da tortura", isto é, um enorme medo de ser torturada. No entanto, de modo oposto ao observado na maioria das narrativas testemunhais, há um desfecho feliz para a protagonista, ainda que sua atitude surpreendente tenha acarretado uma série de eventos catastróficos para a organização delatada.

A construção da personagem Dodora muito provavelmente foi inspirada na pessoa física de Maria Auxiliadora Lara Barcelos, também apelidada de Dodora ou Dora. Em Você vai voltar pra mim e outros contos (2014), Kucinski alerta seus leitores sobre essa possível identificação: "Aos leitores familiarizados com aqueles tempos, os contos podem lembrar episódios e pessoas conhecidas. Mas não passam de invenções, criações literárias sem nenhuma obrigação de fidelidade a pessoas ou fatos que eventualmente os possam ter inspirado" (KUCINSKI, 2014, p. 7). Por um lado, se tal assertiva atesta a autonomia da escrita literária, por outro acentua o teor testemunhal da obra a partir da presença de elementos factuais, demarcando a íntima relação entre ficção e história.

Nesse sentido, sem descentralizar o texto literário, se estabelecerá um diálogo entre elementos extratextuais, no caso, dados biográficos da pessoa que inspirou a protagonista Dodora do conto homônimo, com o intuito de discutir a construção dessa personagem. Assim, propõe-se como hipótese que a construção de um desfecho positivo para essa personagem, diferente do que aconteceu no plano real, se deve à empatia e ao compromisso ético do escritor Kucinski com as vítimas do regime militar brasileiro.

O conto inicia-se com as lembranças do narrador-personagem sobre os encontros com os amigos, ex-militantes, nos quais rememoravam suas ações contra o regime ditatorial: 
De quando em quando eu me reunia com amigos para relembrar nossos tempos de universidade e nossas investidas contra a ditadura. Sempre na casa do Alberto e sempre os mesmos cinco: além dele, eu, o Nilo, o Ferreira e o Piauí. Deles ouvi, pela primeira vez, o nome Dodora (KUCINSKI, 2014, p. 82).

A partir da expressão "de quando em quando", constata-se a recorrência das memórias da ditadura, o que torna possível inferir que existe algo desse passado ainda não elaborado que, portanto, persiste no presente. A respeito dessa memória do passado no tempo presente, Sarlo (2007), baseada nos estudos de Ricouer, elucida que

A hegemonia do presente sobre o passado no discurso é da ordem da experiência e se apoia, no caso do testemunho, na memória e na subjetividade. A rememoração do passado [...] não é uma escolha, mas uma condição para o discurso, que não escapa da memória nem pode livrar-se das premissas impostas pela atualidade à enunciação. E, mais que uma libertação dos 'fatos' coisificados, como Benjamin desejava, é uma ligação, provavelmente inevitável, do passado com a subjetividade que rememora no presente (SARLO, 2007, p. 49).

Desse modo, a constante rememoração da experiência da ditadura aponta uma certa influência desse passado no presente dos personagens, ou seja, a mudança de suas subjetividades, provocadas pelas práticas repressivas do regime militar, impossibilita um distanciamento dos tempos de outrora. Além disso, a atualidade do discurso testemunhal, considerando a lacuna na reparação de crimes da ditadura, demanda a lembrança frequente desse período.

Tendo em vista a pouca atenção à política da memória das vítimas do regime militar brasileiro, por vias oficiais, depreende-se que a nomeação de todos os amigos, exceto o nome de quem narra, constitui uma estratégia narrativa para dar visibilidade à história dos vencidos, para não esquecer esses anônimos da história.

Ainda sobre o parágrafo que inicia o conto, chama a atenção a súbita referência ao nome de Dodora, que, aparentemente, é ou foi alguém importante, pois se o narrador destaca que foi a primeira vez que ouviu falar sobre a mulher, provavelmente ela é assunto recorrente nas reuniões com os amigos ou será assunto da narrativa, como o próprio nome 
do conto já antecipa. Adiante, o narrador destaca ainda a afetividade nas memórias de seus colegas:

Recordavam com nostalgia profunda cada nome, cada episódio daqueles tempos. As manias desse ou daquele, as batalhas ideológicas. As perdas. Falaram de quando explodiu o fusquinha, matando três companheiros, de quando caiu fulano num assalto a banco, de quando cicrano [sic] bandeou para outro grupo levando o jipe da organização. E falaram da Dodora (KUCINSKI, 2014, p. 82-3).

A mudança do foco narrativo para a terceira pessoa deve-se ao fato de o narrador ter vivido pouco tempo na residência estudantil, diferente dos amigos; portanto, esse narrador constitui uma testemunha que escapa à noção de superstes e testis. Ainda que haja um maior distanciamento do narrador em relação a tais recordações, observa-se que a memória daqueles que se opuseram ao regime militar é novamente recuperada.

Sua "nostalgia profunda" aponta um afeto por aqueles que não sobreviveram e reitera o dever de manter a memória desses companheiros. Essa constatação pode ser confirmada com o curto período "As perdas", no qual fica nítido o seu caráter de indizibilidade. Mas, apesar de o narrador citar acontecimentos que envolvem diferentes pessoas, observase que estas micro-histórias são secundárias, pois seus protagonistas são anônimos ("fulano”, “cicrano”) e não têm suas histórias desenvolvidas. Entretanto, o nome de Dodora é pela segunda vez citado, a qual tem sua história expandida:

Sempre falavam da Dodora. Da firmeza de suas convicções, da sua coragem nas ações. Ela é que tinha colhões, diziam brincando, pois era a única mulher a participar das ações armadas. Percebi que, invariavelmente, após algumas reminiscências a conversa estancava. Logo se calavam, compungidos, como se súbito se lembrassem de algo inominável. Mudavam de assunto (KUCINSKI, 2014, p. 83).

A figura de Dodora como participante das ações armadas traz a memória de muitas mulheres que romperam com a cultura patriarcal da época dentro da esquerda, ao marcarem presença ativa na luta contra a ditadura, presença esta apagada da história oficial. A exclusividade da vida pública aos homens confirma-se na narração sobre Dodora: "Ela é 
que tinha colhões, diziam brincando, pois era a única mulher a participar das ações armadas" (KUCINSKI, 2014, p. 83). O uso do termo "colhões", que simboliza masculinidade, aponta que a luta política era um espaço essencialmente masculino, ao passo em que uma mulher que rompia com essa lógica precisava ser comparada a um homem. Contudo, é sabido que muitas mulheres, a exemplo de Dodora, Ana Rosa, Aurora, Dilma Rousseff, Dina do Araguaia, Iara Iavelberg, Olga Benário, entre outras, marcaram dupla oposição ao controle e repressão, isto é, ao regime autoritário e ao patriarcado.

Apesar de Dodora se destacar por ser a única mulher na luta armada contra a ditadura, é evidente que esta não é a razão principal para que ela seja sempre lembrada. O desvio das conversas sobre tal mulher contrasta com a descrição positiva das ações dela: "Sempre falavam da Dodora. Da firmeza de suas convicções, da sua coragem nas ações". Nota-se que não se predica o sujeito, mas suas ações, o que indica uma maior importância do agir da personagem do que sua subjetividade. O deslocamento das lembranças sobre Dodora e a suposição de que os amigos recordavam de "algo inominável" também sinalizam possíveis cicatrizes, traumas não elaborados e que, portanto, ainda não podem ser verbalizados.

A suspensão destas lembranças incita a curiosidade do narrador, o qual começa a fazer conjecturas sobre o paradeiro de Dodora: "Fiquei muito curioso. Por que de repente se fechavam? O que de tão terrível acontecera para provocar esse silêncio? Será que essa Dodora havia sido torturada, talvez estuprada ou esquartejada? Será que foi desaparecida pela ditadura?” (KUCINSKI, 2014, p. 83). Desse modo, várias práticas do regime de exceção são expostas na tentativa de explicar o silêncio dos companheiros sobre o que aconteceu com a protagonista do conto. Esse silêncio é compreensível ao passo em que o testemunho se encontra entre a necessidade e a impossibilidade de narrar experiências-limite. Ainda nessa direção, vale pensar esse silêncio em diálogo com a própria sonoridade do nome da personagem, a qual remete à dor, que também é indizível. 
$\mathrm{Na}$ perspectiva de desvendar a história de Dodora, o narrador-personagem resolve perguntar ao seu amigo Alberto sobre a tal mulher. A seguir, o narrador, em discurso indireto, passa a testemunhar o que ocorrera:

O nome dela, ele disse, era Maria Auxiliadora. Estudava filosofia e vinha de uma família de velhos comunistas do interior de São Paulo. Já chegou politizada e logo se engajou na organização. Participava de ações de expropriação sem pestanejar. Parecia querer vingar o pai, que, já idoso, ainda sofria de sequelas da prisão na ditadura do Getúlio. Era uma garota robusta e destemida. Mas tinha outro lado muito sensível e um tanto instável. Chegava a chorar ao ler relatos de presos supliciados. Também não percebemos, contou o Alberto, que tomava uma pílula, ou não demos importância. O fato é que, passado algum tempo, a Dodora foi demonstrando um nervosismo crescente e o cacoete de olhar para trás e para os lados o tempo todo, como se temesse estar sendo seguida. Isso tudo, disse o Alberto, só foi lembrado depois, quando tentaram entender o que aconteceu naquela madrugada (KUCINSKI, 2014, p. 83).

A partir desse excerto, muitas informações sobre Dodora são postas, na perspectiva de delinear um caminho que revele o paradeiro dessa mulher. O primeiro dado revelado é que Dodora é um codinome, já que seu nome é Maria Auxiliadora, o que confirma a referência à pessoa física de Maria Auxiliadora Lara Barcelos, membro da organização Vanguarda Armada Revolucionária Palmares (VAR-Palmares) ${ }^{2}$. No entanto, opta-se por dar continuidade à análise da narrativa, antes de relacionarmos a construção da personagem com a biografia da pessoa física que, provavelmente, a inspirou.

Vinda de família engajada na luta contra regimes de exceção, nota-se, em Dodora, um empenho nas ações contra a ditadura, talvez motivado por um sentimento de justiça pelas sequelas que seu pai ainda carregava após ter sido preso, e provavelmente torturado, na ditadura Vargas. Nesse sentido, partindo da ideia de que as sequelas traumáticas são transgeracionais, justifica-se a condição de constante medo de Dodora, ao passo em que,

\footnotetext{
${ }^{2}$ Os dados sobre Maria Auxiliadora Lara Barcelos foram obtidos através do portal Memórias da ditadura, disponível em: <http://memoriasdaditadura.org.br/biografias-da-resistencia/maria-auxiliadora-lara-barcelos/index.html>.
} 
além de ser filha de uma vítima da violência política, ouviu muitos relatos de companheiros torturados. A respeito da possibilidade de transferência do trauma entre gerações, Martín (2005), em seu artigo “As sequelas psicológicas da tortura”, elucida que

as sequelas psicológicas da tortura são crônicas e têm duração transgeneracional [sic]; assim, por exemplo, foi demonstrado com descendentes de famílias de judeus exterminadas nos campos de concentração nazistas. Com efeito, os grupos terapêuticos realizados em Paris, reunindo familiares da terceira geração da "Shoah", têm evidenciado diversos sintomas desses traumatismos, presentes na afiliação, na memória familiar, nos "buracos negros" da história de cada um, nos silêncios do impossível de dizer e simbolizar (MARTÍN, 2005, p. 439).

Considerando que, assim como os pais, Dodora é uma militante de esquerda, podese inferir que ela foi educada para a resistência, mas também vivenciou, direta ou indiretamente, as cicatrizes de seus pais oriunda da ditadura do Estado Novo, seja por meio de relatos das memórias traumáticas da época, seja pelas sequelas físicas e/ou psicológicas carregadas por seus progenitores.

Forças antagônicas se apresentam na característica da personagem: "robusta e destemida" por um lado, "sensível e um tanto instável", por outro. Esse antagonismo se relaciona com as "tensões externas" que constituem o pano de fundo da narrativa. A revelação de que a personagem tomava uma pílula, e de que ela aparentava estar imersa em estado de medo, tal como tio André, do conto homônimo analisado, permite a inferência de que Dodora sofre de algum distúrbio psíquico ou emocional provocado pelo próprio contexto altamente repressivo:

Também não percebemos, contou o Alberto, que tomava uma pílula, ou não demos importância. $O$ fato é que, passado algum tempo, a Dodora foi demonstrando um nervosismo crescente e o cacoete de olhar para trás e para os lados o tempo todo, como se temesse estar sendo seguida" (KUCINSKI, 2014, p. 83).

Entretanto, observa-se que a mudança de comportamento de Dodora é a ponta do iceberg, pois a maior inflexão ainda não foi exposta: "Isso tudo, disse o Alberto, só foi 
lembrado depois, quando tentaram entender o que aconteceu naquela madrugada" (KUCINSKI, 2014, p. 83). O despercebimento do uso de medicamentos por Dodora, bem como sua condição apreensiva, pode ser justificado pelo momento de constante terror que todos os companheiros estavam submetidos. Por isso, então, esses detalhes só foram lembrados depois do que se sucedeu:

A ação em si fora de pouco risco. Dodora e alguns outros estavam pichando Abaixo a Ditadura, quando dois carros trombaram na esquina próxima e um deles incendiou-se. Obviamente veio polícia, corpo de bombeiros, ambulância. Deu a maior confusão. Dodora podia simplesmente ter se mandado, como fizeram os outros; a polícia estava ligada no desastre, não nas pichações. Mas, em vez de cair fora, ela se enfiou num dos carros da polícia e ali ficou. Os policiais acharam que era uma doida qualquer e mandaram que saísse. Mas ela se recusou a deixar o carro. Disse que tinha algo muito importante para revelar. Tanto insistiu que foi levada à delegacia. $\mathrm{Na}$ delegacia, confessou ao atônito delegado de plantão que fazia parte de um grupo que assaltava bancos para financiar a revolução. Foi transferida na mesma noite para o Dops. Lá descreveu calmamente todas as ações das quais participou e, o que é pior, entregou todos os nomes que conhecia, um por um, com endereços, telefones, pontos e outros detalhes que sabia. Só então se convenceram de que ela falava a verdade. Os dados batiam com o que eles sabiam. Disseram que ela ainda teve o cuidado de pedir um escrivão e foi ditando tudo bem devagar, para que nenhuma informação se perdesse, ou para que não precisassem perguntar depois. A organização foi dizimada. Muitos caíram, alguns foram mortos. Poucos escaparam (KUCINSKI, 2014, p. 84-5).

A partir desse longo excerto, desvenda-se o motivo do silêncio dos amigos do narrador sobre Dodora e instaura-se uma maior tensão na narrativa. A ação da personagem é imprevisível porque, apesar da delação ser algo comum em contextos repressivos, ela não o fez a partir de uma ação concreta do regime de exceção: "Dodora podia simplesmente ter se mandado, como fizeram os outros; a polícia estava ligada no desastre, não nas pichações. Mas, em vez de cair fora, ela se enfiou num dos carros da polícia e ali ficou" (KUCINSKI, 2014, p. 84). Assim, a atitude da protagonista foge ao esquema revolucionários x 
reacionários, contracorrente x status quo, pois Dodora "colabora" com aqueles que, até então, eram seus opositores. Entretanto, é a situação de medo que implode o engajamento e valores da personagem.

Esse tipo de delação impulsionada pela máquina da tortura fora antes tematizado no filme Ação entre amigos (1998), de Beto Brant. Semelhante aos contos de Kucinski, a produção cinematográfica confirma a perenidade das sequelas da ditadura, os fantasmas do passado sob as diferentes perspectivas dos personagens. O enredo do filme se desenvolve a partir de um determinado presente, vinte e cinco anos após a ditadura, no qual quatro amigos (Elói, Miguel, Paulo e Osvaldo) viajam a convite de Miguel, que planeja encontrar e matar seu torturador, Correia.

No entanto, a grande complicação da narrativa se dá com a revelação sobre o paradeiro do algoz dos amigos, que está vivo e perto do sítio onde os companheiros iriam passar um fim de semana pescando. Outro ponto problemático da obra cinematográfica é a delação feita, na época da ditadura, por um dos quatro amigos, o que provocou sérias consequências.

Além de colocar em xeque os dilemas éticos dos militantes e das consequências irreversíveis da delação motivada pela tortura, o filme de Brant destaca a relação entre um passado conflituoso e um presente marcado por memórias traumáticas em aberto, sem responsabilização oficial, assim como Kucinski trata em sua literatura.

Voltando ao conto em análise, nota-se que a polícia considera, a princípio, a atitude da mulher como uma manifestação da loucura: "Os policiais acharam que era uma doida qualquer e mandaram que saísse. Mas ela se recusou a deixar o carro" (KUCINSKI, 2014, p. 84). Isto porque não se espera que um militante entregue seus companheiros espontaneamente. No entanto, observa-se que após as informações serem úteis para a polícia, o discurso de Dodora passa a ter enorme validade, ela já não é considerada uma "doida qualquer".

Além da ação impulsiva de Dodora ser surpreendente, é intrigante como a mulher se dispõe a delatar seu grupo de maneira tão detalhada e fria: 
Lá descreveu calmamente todas as ações das quais participou e, o que é pior, entregou todos os nomes que conhecia, um por um, com endereços, telefones, pontos e outros detalhes que sabia. Só então se convenceram de que ela falava a verdade. Os dados batiam com o que eles sabiam. Disseram que ela ainda teve o cuidado de pedir um escrivão e foi ditando tudo bem devagar, para que nenhuma informação se perdesse, ou para que não precisassem perguntar depois (KUCINSKI, 2014, p. 84-5, grifos nossos).

Dodora expõe detalhadamente todos os seus companheiros, talvez para garantir a autenticidade de seu discurso. A princípio, o gesto da mulher parece ser motivado por um sentimento de egoísmo, que muito contrasta com os sentimentos de solidariedade e coletividade característicos de grupos de esquerda. Porém, ao considerar que a mulher assim fez "para que não precisassem perguntar depois", infere-se que sua ação abrupta foi motivada exclusivamente pelo medo de precisar delatar sob práticas de tortura.

Apesar do saldo negativo, a prisão e morte de companheiros, a organização delatada por Dodora nada faz contra ela. O narrador revela, a partir do que Alberto conta, que inicialmente justificaram a atitude da mulher pela loucura: "Perguntei ao Alberto se a organização não tomara alguma medida contra ela. Ele disse que não. Espalharam que ela havia enlouquecido e que a família a tinha internado para tratamento. Tudo teria acontecido porque naquele dia ela não se medicara" (KUCINSKI, 2014, p. 85). Observa-se que a loucura aparece novamente para justificar a ação de Dodora, só que, diferentemente da polícia, os militantes tentam acreditar nesse provável distúrbio psicológico, pois seria o único argumento razoável para explicar a irresponsável postura da companheira.

Aqui vale ressaltar algumas inquietações de Viñar sobre a dificuldade de manter a lucidez e a coerência com seus ideais diante de uma experiência-limite como a ditadura: "Por quais caminhos a tortura conduz à alucinação? De que maneira o louco que portamos em nós, e que emerge nesta situação extrema, pode servir a valores éticos tão antinômicos e nos conduzir à alternativa tão seguidamente apresentada entre o herói e o traidor?” (VIÑAR, 1992, p. 58-59). Nessa perspectiva, entende-se que o medo de ser torturada acaba servindo interesses opostos ao de Dodora, e, nessa condição, a mulher poderia ser considerada uma "heroína" pelos militares, ao denunciar aqueles que consideravam inimigos da 
pátria, e por outro lado, "traidora" pelos companheiros. No entanto, a partir da voz narrativa, constata-se que, diferente do que se espera, a organização não repreende a atitude da mulher, o que, talvez, se explique pela consciência da dificuldade de se manter lúcido na circunstância aterrorizante que viviam.

Não obstante, "muito tempo depois, surgiria outra versão, negando que ela tivesse esquecido o remédio e que tivesse sido internada. Disseram que, ao contrário, subitamente todos os seus cacoetes sumiram e ela sentira um enorme alívio" (KUCINSKI, 2014, p. 85). A partir desse outro ponto de vista, constata-se que a delação foi feita para se livrar do constante medo de ser perseguida, quiçá torturada, ou mesmo pelo demasiado peso que os militantes carregavam, ao assumirem uma postura de combate e resistência ao regime militar. Assim, não há um desfecho certo para o que levou Dodora realizar tal ação. Contudo, diante dessas duas versões, o narrador-testemunha encerra o conto com o parecer do amigo Alberto sobre o caso de Dodora:

O Alberto acha que foi um caso extremo de síndrome da tortura, comum na época. Disse que os relatos que chegavam à residência estudantil, e talvez outros da época de seu pai, devem ter criado nela tamanho pavor, que Dodora precisou se antecipar e entregar tudo voluntariamente, eliminando, com isso, a necessidade de ser torturada. Perguntei ao Alberto se ela estava viva, o que fora feito dela. Ele contou que Dodora vivia no interior, casou-se, teve filhos e hoje é avó (KUCINSKI, 2014, p. 85).

A conclusão de Alberto sobre o caso de Dodora não invalida nenhuma das duas proposições anteriores, porque, de fato, a mulher sofria um distúrbio psicológico, no entanto, provocado pelo clima opressivo, mais especificamente pelo medo de ser torturada. Conforme Martín (2005, p. 436), "não há uma patologia específica da tortura”, entretanto entende-se a "síndrome da tortura", assim nomeada pelo personagem, como um efeito do tempo repressivo e autoritário em que viviam, capaz de desestabilizar a pessoa, antes mesmo da tortura.

Viñar elucida que "a tortura cria no espaço social algo como um referente de punição, cujos efeitos trágicos visam não somente à vítima, mas, através dela, o grupo social no 
qual provoca o medo e a paralisia" (VIÑAR, 1992, p. 73). Sob essa perspectiva, pode-se pensar que a tortura dos companheiros de Dodora, conhecida pelos relatos que recebia, foi capaz de atingir não somente a mulher, mas toda a organização da qual fazia parte, isto porque o conhecimento de tais práticas violentas foi suficiente para instaurar um terror em Dodora ao ponto de paralisá-la na ação, e assim delatar o seu grupo.

Em "Pedro ou a demolição: um olhar psicanalítico sobre a tortura", Viñar (1992) apresenta a história de um "anti-herói e seu fracasso", de um militante latino-americano, Pedro, que, ao ser torturado, acaba tendo sua identidade manipulada, levando à delação de seus companheiros. Porém, diferentemente de Dodora, Pedro não conseguiu conviver com o olhar de desaprovação dos seus, carregar o peso de ter agido como um "traidor" e, assim, vive fugindo da realidade e de si mesmo. Logo, ele acaba se distanciando da esposa, que é militante, porque a imagem dela o faz lembrar de sua "covardia". No entanto, chega um momento em que a luta se torna impossível diante da ação militar, e isso acaba viabilizando que Pedro volte a conviver com os seus.

Apesar de Dodora não ter sido torturada antes da delação, nem ter o destino de Pedro, ela também pode ser considerada uma anti-heroína, que tem suas ações determinadas pelo conhecimento da prática da tortura e sua força ameaçadora. Nessa direção, cabe discutir os três momentos da experiência da tortura, propostos por Viñar, a fim de estabelecer uma relação com o caso de Dodora:

- o primeiro momento, o mais conhecido, visa a aniquilação do indivíduo e a destruição de seus valores e de suas convicções;

- o segundo momento desemboca numa experiência de desorganização da relação do sujeito consigo mesmo e com o mundo, o que chamei, segundo a expressão lúcida deste paciente [Pedro], a demolição;

- o terceiro momento é a resolução desta experiência limite" (VIÑAR, 1992, p. 45, grifos do autor).

Ainda que Dodora tenha evitado a tortura física, compreende-se que, de certa forma, todos que resistiam ao aparelho repressor do Estado estavam submetidos a uma 
tortura psicológica, através da perseguição e possibilidade de ser preso e torturado fisicamente. Assim, depreende-se que, dada as condições do contexto político, Dodora tem sua subjetividade alterada, o que leva à ruptura de seus valores éticos e sua convicção política. Dessa forma, a entrega espontânea de seus companheiros justifica-se por essa demolição, a qual não permite uma clara dissociação entre os algozes e os torturados, os inimigos e os amigos. Destarte, diante do terror psicológico da época, a personagem vê a delação como única saída para esta situação-limite.

Viñar compreende que a tortura provoca uma alteração dos valores éticos, assim como o terror e o desamparo motiva essa relação entre torturado e torturador:

A submissão e a aliança com o inimigo, dos quais a confissão e a delação são os produtos visíveis exteriormente, são o resultado da instauração de uma relação de cumplicidade perversa entre o prisioneiro e seus torturadores. Relação que se origina na necessidade de conjurar o pavor do espaço destruído, preenchendo com o demônio que se queira exorcizar. Assim como o delírio é a cura monstruosa da catástrofe psicótica, a relação de submissão perversa e masoquista é o produto da degradação que substitui o abandono da demolição (VIÑAR, 1992, p. 49).

Por isso, ainda que a ação de Dodora tenha acarretado consequências irreversíveis aos companheiros, observa-se que não há um caráter moralizante no conto de Kucinski, a fim de julgar a personagem. Isto porque entende-se que o principal motivador de todo esse infortúnio foi o próprio contexto repressivo, a atmosfera de medo que envolvia os tempos de outrora.

Contudo, o mais intrigante em "Dodora" é que, diferente dos outros contos de Kucinski, de forma imprevisível e irônica, a protagonista tem um "final feliz". Descartada a possibilidade de ser torturada, Dodora passa a ter uma vida tranquila, enquanto os companheiros delatados tiveram seus sonhos interrompidos, ou mesmo suas vidas ceifadas.

O desfecho do conto de Kucinski, muito provavelmente, provocou parte de seus leitores, pois questiona-se "como é possível a personagem ficar incólume após a delação dos companheiros?". No entanto, ao retomar a relação entre a construção da personagem 
Dodora e a pessoa física que a inspirou, é interessante pensar que, talvez, Kucinski reinventou a realidade, dando um outro rumo para a história dessa mulher, muito mais pela pessoa de Maria Auxiliadora, que não delatou ninguém, do que pela personagem construída em sua homenagem.

Maria Auxiliadora Lara Barcelos, Dodora, estudante de medicina, foi presa em 1969, junto a Antônio Roberto Espinoza e Chael Charles Schreier, os quais foram extremamente torturados3. Após o sequestro do embaixador suíço Giovanni Bucher, em 1971, Dodora e mais sessenta e nove presos políticos foram banidos para o Chile. Lá foi entrevistada por Haskell Wexler, cineasta norte-americano, que produziu o documentário Brazil: a report on torture4, no qual, através do depoimento de recém-exilados, denuncia as práticas de tortura do regime militar brasileiro.

Com o golpe militar no Chile, Dodora se refugia, em 1973, na Bélgica, e em 1974 consegue asilo na Alemanha Ocidental, onde continua os estudos na Universidade Livre de Berlim. No entanto, com a instável vida no exílio e os traumas da tortura sofrida no Brasil, Maria Auxiliadora acaba sendo internada em uma clínica psiquiátrica em Spandau e, em 1976, aos 31 anos de idade, comete suicídio, ao se atirar nos trilhos de um trem, em Berlim5.

Antes de sua morte, Dodora havia escrito suas memórias do exílio, nas quais se inscrevem as traumáticas lembranças da tortura:

Pisei no calcanhar do monstro, e ele virou sua pata sobre mim, cego e incontrolável. Fui uma das vítimas inumeráveis do machão crioulo, monstro verde-amarelo de pés imensos de barro.

Foram intermináveis dias de Sodoma. Me pisaram, cuspiram, me despedaçaram em mil cacos. Me violentaram nos meus cantos mais íntimos.

\footnotetext{
${ }^{3}$ Gaspari (2002), em $A$ ditadura escancarada, descreve as torturas às quais Dodora e companheiros foram submetidos, a partir de depoimentos.

${ }^{4}$ O documentário está disponível no youtube: <https://www.youtube.com/watch?v=YlQKL707vro >.

5 Os dados sobre Maria Auxiliadora Lara de Barcelos foram obtidos através de Barcellos (1978), Projeto Brasil: nunca mais (1985) e do site Memórias da ditadura.
} 
Foi um tempo sem sorrisos. Um tempo de esgares, de grito sufocados, um grito no escuro.

A Apologia da Violência. A luta pelo poder absoluto. A destruição do outro, da antítese de sua alma negra (BARCELLOS, 1978, p. 317).

Recuperam-se tais dados biográficos a título de trazer a memória dos esquecidos da história, assim como denunciar as práticas autoritárias que silenciaram essas pessoas, a exemplo de Dodora. Esse dever ético com a memória das vítimas do regime militar brasileiro também se cumpre na literatura de Kucinski que, de forma muito sensível, desfaz o trágico fim da história de Dodora, delineando outros caminhos para que a personagem não pereça como na vida real, sem perder de vista que o único inimigo foi o autoritarismo e violência do Estado. Ou seja, a afirmação inicial de Kucinski sobre não ter compromisso com a real existência das histórias e dos personagens, talvez, aponte a impossibilidade de testemunhar a experiência de outrem de forma fidedigna, e a dificuldade de narrar memórias traumáticas, sendo necessário o suporte da imaginação para dar conta de temas-limite, como a violência.

Conforme Seligmann-Silva, “a imaginação é chamada como arma que deve vir em auxílio do simbólico para enfrentar o buraco negro do real do trauma. O trauma encontra na imaginação um meio para sua narração. A literatura é chamada diante do trauma para prestar-lhe serviço" (SELIGMANN-SILVA, 2008, p. 70). Desse modo, a impossibilidade de testemunhar a realidade traumática de Dodora leva Kucinski a reinventar, através do espaço ficcional, a cena traumática.

Se "o testemunho [se constitui] como híbrido de singularidade e de imaginação, como evento que oscila entre a literalidade traumática e a literatura imaginativa" (SELIGMANN-SILVA, 2008, p. 72), pode-se compreender a construção da personagem de Dodora que, apesar de lembrar a pessoa que a inspirou, tem seu destino traçado a partir de outras escolhas desenhadas por Kucinski. A empatia e imaginação do escritor salvam a personagem de um desfecho trágico, sem apagar os rastros dos tempos de outrora.

Diante da necessidade e impossibilidade de narrar o trauma, a ficção se apresenta, portanto, como via de elaboração de situações-limite, sem perder de vista os valores éticos 
do testemunho. Assim, "Dodora” não é apenas ficção, pois, a partir de elementos factuais, retoma memórias traumáticas da ditadura.

\title{
LITERATURE AND REPRESSION: AN ANALYSIS ON “DODORA” SHORT STORY, BY BERNARDO KUCINSKI
}

\begin{abstract}
The article analyzes the short story "Dodora", by Bernardo Kucinski, published in Você vai voltar pra mim e outros contos (2014), a work of testimonial content that thematizes the context of the Brazilian civil-military dictatorship. Although the book has been published after the process of redemocratization, it is necessary to remember the past in the present time, in the perspective of avoiding the perpetuation of the authoritarianism of the past. In the meantime, the traumatic impacts of the dictatorship are discussed, especially the "torture syndrome", a constant fear provoked by the climate of oppression of the time. The proposed reading of Kucinski's short story, therefore, is oriented to understand how the literature produced in the context of post-civil-military dictatorship elaborates political repression and its aftermath. For this, this study, eminently bibliographical, resorts to scholars from several areas of knowledge, among them, Ginzburg, Sarlo, Seligmann-Silva and Viñar.
\end{abstract}

KEYWORDS: Civil-military dictatorship; Literature of testimony; Memory; Torture; Trauma.

\section{REFERÊNCIAS}

BARCELLOS, Maria Auxiliadora Lara. "Continuo sonhando". In: CAVALCANTI, Pedro Celso Uchôa; RAMOS, Jovelino. Memórias do exílio - Brasil 1964/19??. São Paulo: Livramento, 1978.

BRAZIL: a report on torture. Direção de Hannah Eaves. Estados Unidos: 1971. 60 min., son., color.

GASPARI, Elio. A ditadura escancarada. São Paulo: Companhia das Letras, 2002.

GINZBURG, Jaime. Linguagem e trauma na escrita do testemunho. In: Conexão Letras. Porto Alegre: 2008, v. 3, n. 3, p. 61-66. Disponível em: < http://seer.ufrgs.br/index.php/conexaoletras/article/view/55604/33808>. Acesso em: 15 maio. 2018.

HOBSBAWM, Eric J. Era dos extremos: o breve século XX: 1914-1991. São Paulo: Companhia das Letras, 1995.

KUCINSKI, Bernardo. K. São Paulo: Expressão Popular, 2011.

. Você vai voltar pra mim e outros contos. São Paulo: Cosac Naify, 2014. 
LEMOS, Lara de. Inventário do medo. São Paulo: Massao Ohno Editor, 1997.

MARTÍN, Alfredo Guillermo. As sequelas psicológicas da tortura. In: Revista Psicologia ciência e profissão. Brasília: 2005, vol. 25, n. 3, p. 434-449. Disponível em: < http://pepsic.bvsalud.org/scielo.php?script=sci_arttext\&pid=S1414-98932005000300008>. Acesso em: 17 jan. 2019.

MEMÓRIAS DA DITADURA. Maria Auxiliadora Lara Barcelos. In: Biografias da resistência. Disponível em: <http://memoriasdaditadura.org.br/biografias-da-resistencia/mariaauxiliadora-lara-barcelos/index.html>. Acesso em: 27 dez. 2018.

PROJETO BRASIL: nunca mais. Tomo V: Os mortos. São Paulo/Petrópolis: Arquidiocese de São Paulo/Vozes, 1985, vol. 4.

SARLO, Beatriz. Tempo passado: cultura da memória e guinada subjetiva. Tradução Rosa Freire d'Aguiar. São Paulo: Companhia das Letras; Belo Horizonte: UFMG, 2007.

SELIGMANN-SILVA, Márcio. Literatura e trauma: um novo paradigma. In: O local da diferença: ensaio sobre memória, arte, literatura e tradução. São Paulo: Editora 34, 2005, p. 63-80.

. Narrar o trauma - a questão dos testemunhos de catástrofes históricas. In: Revista Psicologia Clínica. Rio de Janeiro: 2008, vol. 20, n.1, p. 65-82.

VIÑAR, Marcelo; VIÑAR, Maren. Exílio e tortura. São Paulo: Escuta, 1992.

Recebido em: 30/05/2019.

Aprovado em: 26/07/2019. 